\title{
Cyclosporin A Inhibits CD40 Ligand Expression in T Lymphocytes
}

\author{
Ramsay Fuleihan, * Narayanaswamy Ramesh, * Anthony Horner, * Deborah Ahern, * Peter J. Belshaw," David G. Alberg," \\ Ivan Stamenkovic, ${ }^{3}$ William Harmon, ${ }^{\star}$ and Raif S. Geha* \\ Divisions of *Immunology and ${ }^{\ddagger}$ Nephrology, The Children's Hospital, and ${ }^{\S}$ Departments of Pediatrics and Pathology, Harvard Medical \\ School, Boston, Massachusetts 02115; and "Department of Chemistry, Harvard University, Cambridge, Massachusetts 02138
}

\begin{abstract}
The ligand for CD40 is expressed on activated T lymphocytes and delivers contact-dependent activation signals to B lymphocytes. The mechanisms regulating CD40 ligand gene expression are largely unknown. Optimal expression of CD40 ligand required activation of protein kinase $\mathrm{C}$ and a rise in intracellular calcium concentration. CD40 ligand expression was inhibited by pretreatment of $T$ cells with cyclosporin $A$. Cyclosporin $A$ analogues inhibited CD40 ligand expression with a potency mirroring the ability of each compound to inhibit calcineurin activity, indicating that calcineurin plays a key role in CD40 ligand gene expression. Cyclosporin $A$ inhibited IL-4-driven CD40 ligand-dependent IgE isotype switching in PBMC but did not inhibit IgE synthesis induced by CD40 mAb plus IL-4. PBMC derived from transplant patients receiving cyclosporin $A$ failed to express CD40 ligand upon stimulation. These results suggest that patients receiving cyclosporin A may be deficient in CD40 ligand-dependent T cell help. ( $J$. Clin. Invest. 1994. 93:1315-1320.) Key words: gene activation • calcineurin • transcription factors • transplantation • immunosuppressants
\end{abstract}

\section{Introduction}

Humoral immunity is critically dependent on interaction between $T$ and $B$ lymphocytes. T cells secrete cytokines necessary for $B$ cell differentiation and activate $B$ cells in a contact-dependent manner (1). A prime candidate for the $T$ cell surface molecule that delivers the contact-dependent signal is the recently described ligand for the B cell antigen CD40 (2-5). The CD40 ligand (CD40L) ${ }^{1}$ is a $39-\mathrm{kD}$ type II membrane glycoprotein expressed on activated $\mathrm{T}$ cells. It is homologous to tumor necrosis factor (4), while its counterreceptor on B cells, CD40, is a member of the tumor necrosis factor receptor/nerve

Address correspondence to Ramsay Fuleihan, M.D., Division of Immunology, The Children's Hospital, 300 Longwood Avenue, Boston, MA 02115.

Received for publication 14 May 1993 and in revised form $23 \mathrm{No}$ vember 1993.

1. Abbreviations used in this paper: $\left[\mathrm{Ca}^{2+}\right]_{\mathrm{i}}$, intracellular calcium; CD40L, CD40 ligand; CsA, cyclosporin A; IL-2R $\alpha$, IL-2 receptor alpha chain; NF-AT, nuclear factor of activated T cells; PKC, protein kinase C; sCD40, soluble CD40.

J. Clin. Invest.

(C) The American Society for Clinical Investigation, Inc.

$0021-9738 / 94 / 03 / 1315 / 06 \quad \$ 2.00$

Volume 93, March 1994, 1315-1320 growth factor receptor family (6). Engagement of CD40 on B cells by monoclonal antibody or by CD40L results in B cell activation, proliferation, aggregation, and immunoglobulin isotype switching $(2,4,7-11)$. Soluble forms of CD40 ( $\mathrm{SCD} 40$ ) inhibit T cell-dependent $\mathrm{B}$ cell activation and immunoglobulin isotype switching $(3,12)$. We $(13,14)$ and others $(15-18)$ have recently reported that a defect in the gene encoding CD40L is responsible for X-linked immunoglobulin deficiency with normal or elevated IgM (X-linked hyper IgM). These patients are unable to synthesize immunoglobulins other than $\operatorname{IgM}$ or $\operatorname{IgD}(19,20)$, suggesting that interaction between CD40 on B cells and its ligand on activated T cells is critical for immunoglobulin isotype switching. They also suffer from recurrent infections, particularly Pneumocystis carinii pneumonia, autoimmune disease, and lymphoproliferative disease (21). The role of CD40L in preventing these diseases is unknown. An understanding of the mechanisms regulating the expression of CD40L in T cells is essential to define its role in the immune response. In this report, we demonstrate that activation of protein kinase $C(P K C)$ and of calcineurin is required for CD40L gene expression and that cyclosporin A (CsA) inhibits CD40L gene expression and CD40L-dependent $T$ cell function.

\section{Methods}

Cells and reagents. PBMC and T cells were isolated from healthy volunteers or from transplant patients receiving CsA as previously described (1). T cells were $\geq 98 \% \mathrm{CD} 3$ positive as determined by flow cytometry. PMA, $20 \mathrm{ng} / \mathrm{ml}$, and ionomycin, $0.5 \mu \mathrm{M}$, were obtained from Calbiochem-Novabiochem Corp. (San Diego, CA). CsA was kindly provided by Sandoz Inc. (East Hanover, $\mathrm{NJ}$ ). CsA analogues $\mathrm{MeBm}_{2} \mathrm{t}^{1}-\mathrm{CsA}$ and MeAla $^{6}$-CsA were previously described (22).

Cell surface staining and flow cytometry. Cell surface staining for CD40L was performed $6 \mathrm{~h}$ after stimulation, unless otherwise indicated, using sCD40, a product of fusion of cDNA segments encoding the extracellular domain of CD40 (6) to genomic DNA segments encoding human $\operatorname{IgG}_{1}(3)$ as previously described (13). sCD44, a product of fusion of cDNA segments encoding the extracellular domain of CD44 (23) to genomic DNA segments encoding human $\operatorname{IgG}_{1}(24)$, was used as an isotype control. Cell surface expression of the IL-2 receptor alpha chain (IL-2R $\alpha$ ) was determined $24 \mathrm{~h}$ after stimulation using a fluorescein-labeled CD25 mAb (Beckton Dickinson Immunocytometry Systems, Mountain View, CA ). Stained cells were analyzed by flow cytometry on a FACScan ${ }^{\circledR}$ (Beckton Dickinson Immunocytometry Systems).

Northern blot analysis. Total RNA was extracted from stimulated $\mathrm{T}$ cells at $3 \mathrm{~h}$ after stimulation, unless otherwise indicated, and Northern blot analysis was performed as previously described (13). Northern blots were hybridized with a random primer ${ }^{32} \mathrm{P}$-labeled (Pharmacia LKB Biotechnology Inc., Piscataway, NJ) human CD40L probe (gift 
of Dr. A. Aruffo, Bristol-Myers Squibb Pharmaceutical Research Institute, Seattle, WA), human IL-2 probe (American Type Culture Collection, Rockville, MD), and human IL-2R $\alpha$ probe (gift of Dr. W. Greene, Gladstone Institute, San Francisco, CA).

IgE assay. Induction of IgE synthesis was performed and assayed as previously described (1). PBMC were stimulated with $5 \mathrm{ng} / \mathrm{ml}$ recombinant IL-4 (R\&D Systems, Inc., Minneapolis, MN) or with IL-4 plus $5 \mu \mathrm{g} / \mathrm{ml} \mathrm{CD40} \mathrm{mAb} \mathrm{626.1} \mathrm{(25)} \mathrm{(gift} \mathrm{of} \mathrm{Dr.} \mathrm{S.} \mathrm{M.} \mathrm{Fu,} \mathrm{University} \mathrm{of}$ Virginia School of Medicine, Charlottesville, VA ). $100 \mathrm{ng} / \mathrm{ml} \mathrm{CsA} \mathrm{was}$ added to the cultures as indicated. Culture supernatants were collected on day 10 and assayed for IgE as described (1). Background IgE levels were detected in the presence of $100 \mu \mathrm{g} / \mathrm{ml}$ cycloheximide and were always $<500 \mathrm{pg} / \mathrm{ml}$. The average of two replicate samples is given in the results and represents net IgE synthesis above background.

Patients. Three patients receiving CsA were studied after obtaining informed consent. The first patient (CsA patient 1) was a 12-yr-old male who was studied before a kidney transplant. PBMC were derived from blood samples obtained before and $3 \mathrm{~h}$ after a single dose of 4 $\mathrm{mg} / \mathrm{kg}$ CsA. He had not received any other immunosuppressant at the time of the study. CsA patient 2 was a 19-yr-old female, and CsA patient 3 was a 15 -yr-old male, both of whom were receiving CsA after kidney transplantation and, at the time of the study, had trough blood CsA levels of 124 and $84 \mathrm{ng} / \mathrm{ml}$ (whole blood HPLC), respectively. Both patients were also receiving $15 \mathrm{mg}$ prednisone every other day. Control subjects included healthy adults and a 20 -yr-old female asthmatic patient who was receiving $15 \mathrm{mg}$ of prednisone every other day.

\section{Results}

Activation of $\mathrm{T}$ cells via the $\mathrm{T}$ cell receptor (antigen receptor)/ CD3 complex results in a signaling cascade leading to the phosphorylation of phospholipase $\mathrm{C} \gamma$ on tyrosine residues (26-28). Phospholipase $\mathrm{C} \gamma$ initiates the hydrolysis of phosphatidylinositol bisphosphate into diacylglycerol and inositol trisphosphate $(29,30)$ which activate PKC and induce a sustained rise in intracellular calcium $\left(\left[\mathrm{Ca}^{2+}\right]_{i}\right)$, respectively $(31-33)$. We examined the role of $\mathrm{PKC}$ and $\left[\mathrm{Ca}^{2+}\right]_{i}$ in the expression of CD40L. Direct activation of PKC with PMA resulted in no detectable expression of CD40L (data not shown). Ionomycin, at concentrations which increase $\left[\mathrm{Ca}^{2+}\right]_{\mathrm{i}}$ without activating PKC $(<0.5 \mu \mathrm{M})(34)$, resulted in minimal expression of CD40L ( $\leq 6 \%$ ). Maximal expression of CD40L ( $>60 \%$ ) occurred upon stimulation with both PMA and ionomycin, indicating that activation of $\mathrm{PKC}$ and a rise in $\left[\mathrm{Ca}^{2+}\right]_{\mathrm{i}}$ are required for optimal expression of CD40L. Fig. $1 A$ shows that CD40L can be detected on the surface of $\mathrm{T}$ cells as early as $3 \mathrm{~h}$ after stimulation with PMA and ionomycin. CD40L surface expression peaked at $6 \mathrm{~h}$ after stimulation, started to decline by $8 \mathrm{~h}$, and was barely detectable by $16 \mathrm{~h}$. Northern blot analysis of PMA- and ionomycin-induced CD40L mRNA in T cells is shown in Fig. $1 \mathrm{~B}$. CD40L mRNA was detected as early as $1 \mathrm{~h}$ after stimulation, peaked at $3 \mathrm{~h}$, and had decreased by $6 \mathrm{~h}$ after stimulation, consistent with the kinetics of CD40L surface expression.

The increase in $\left[\mathrm{Ca}^{2+}\right]_{\mathrm{i}}$ that results from engagement of the $T$ cell receptor/CD3 complex causes the activation of $\mathrm{Ca}^{2+}$ / calmodulin-dependent enzymes including the protein phosphatase calcineurin. Calcineurin plays a key role in signal transduction in $\mathrm{T}$ cells $(35,36)$. Calcineurin dephosphorylates the cytoplasmic subunit of the transcription factor, nuclear factor of activated T cells (NF-AT) $(37,38)$, which translocates to the nucleus where together with other proteins it forms a functionally active NF-AT complex that regulates the transcription of the IL-2 gene (39). The activity of calcineurin can be modulated by complexes of immunosuppressant drugs and their endogenous immunophilins, a family of proteins which bind immunosuppressants. One such immunosuppressant is CsA, a natural microbial product which binds to cyclophilin (40). The CsA/cyclophilin complex binds to calcineurin and inhibits its phosphatase activity $(41,42)$. To evaluate the role of calcineurin in the signal transduction pathway leading to the expression of CD40L, we examined the effect of CsA on the expression of CD40L in T cells. Fig. 2 shows that increasing concentrations of CsA inhibited the surface expression of CD40L induced by PMA and ionomycin. Peak inhibition of CD40L surface expression occurred at a concentration of 100 $\mathrm{ng} / \mathrm{ml}$ of $\mathrm{CsA}$, with no further inhibition detected at higher concentrations. In contrast, CsA did not affect the surface expression of IL-2R $\alpha$, except for a minimal decrease in the mean fluorescence intensity of IL-2R $\alpha$ at high concentrations of CsA. CsA inhibited the induction of CD40L mRNA induced by PMA and ionomycin (Fig. 3). As previously reported (43), CsA inhibited the expression of IL-2 mRNA. Peak inhibition of CD40L and IL- 2 mRNA by CsA occurred at a concentration of $100 \mathrm{ng} / \mathrm{ml}$. The induction of both $3.5-$ and 1.5-kb IL-2R $\alpha$ mRNA transcripts $(44,45)$ by PMA and ionomycin was minimally affected by CsA except at higher concentrations. Since mRNA was obtained at $3 \mathrm{~h}$, the inhibition of IL-2R $\alpha$ mRNA was probably due to inhibition by CsA (46) rather than to inhibition of IL-2 which is known to upregulate the expression
A

B

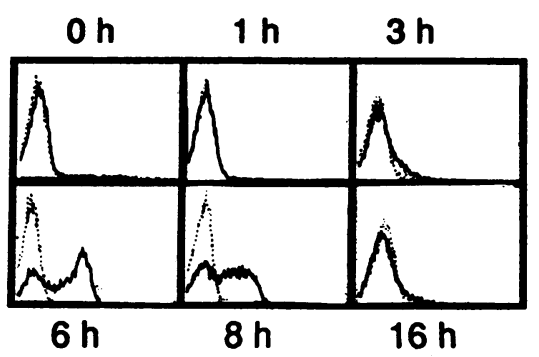

Time (n)

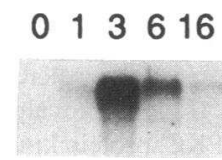

285

185
Figure 1. Kinetics of CD40L expression by PMA and ionomycin. T cells were stimulated by PMA and ionomycin for the indicated periods of time. $(A)$ Cell surface staining for CD40L. CD40L (continuous lines) was detected on the surface of $\mathrm{T}$ cells at $3 \mathrm{~h}(15 \%)$, peaked at $6 \mathrm{~h}(60 \%)$, and started to decline by $8 \mathrm{~h} \mathrm{(50 \% )}$ with minimal expression of CD40L remaining by 16 $\mathrm{h}(<5 \%)$ after stimulation. There was no detectable binding of sCD44 (dotted lines) at any time point. $(B)$ Northern blot analysis of CD40L mRNA expression. CD40L mRNA was detected as early as $1 \mathrm{~h}$, peaked at $3 \mathrm{~h}$, and decreased by $6 \mathrm{~h}$ after stimulation. Ethidium bromide staining of $18 \mathrm{~S}$ and 28S RNA is shown to illustrate the relative concentrations of RNA. 


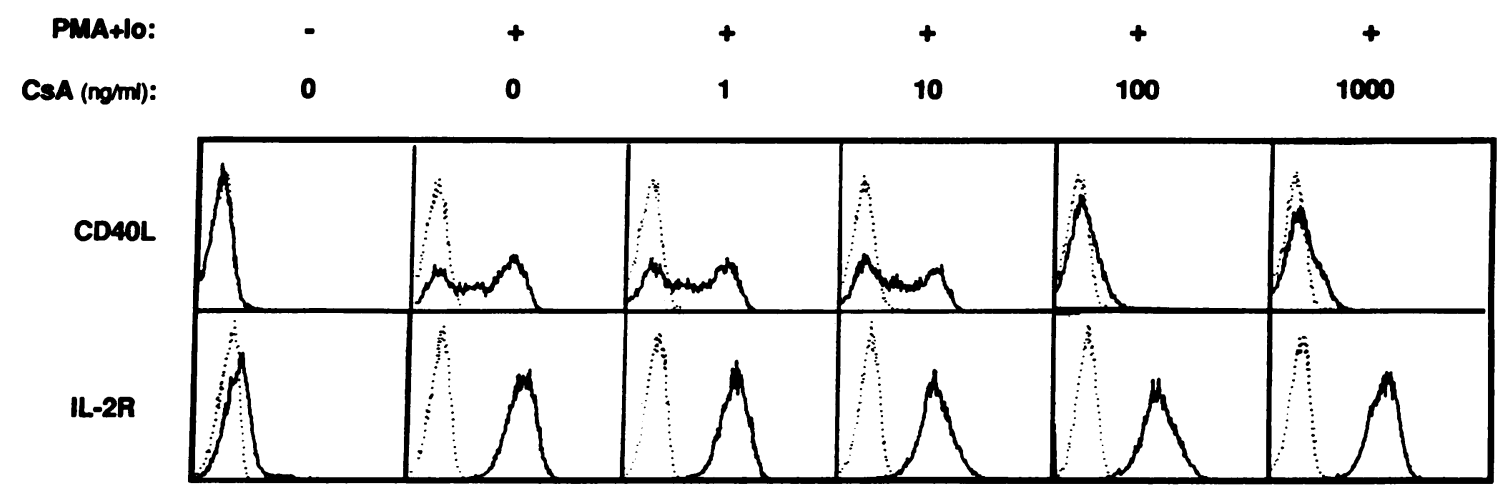

Figure 2. Inhibition of CD40L surface expression by CsA. T cells were preincubated with medium alone or with the indicated concentrations of CsA for $1 \mathrm{~h}$ before stimulation with PMA and ionomycin. CD40L and CD25 are shown by a continuous line, and relevant isotype controls are shown by a dotted line. CsA inhibited cell surface expression of CD40L in T cells in a concentration-dependent manner. CD40L was expressed by $62 \%$ of the $\mathrm{T}$ cells in the absence of CsA and decreased to $58,51,4$, and $8 \%$ with $1,10,100$, and 1,000 ng/ml CsA, respectively. IL-2R $\alpha$ expression was minimally affected by CsA. All stimulated T cells expressed IL-2R $\alpha$ in the presence or absence of CsA. CsA caused a minimal decrease in the mean fluorescence intensity of IL-2R $\alpha$ ( 144 in untreated vs 105 at $1 \mu \mathrm{g} / \mathrm{ml} \mathrm{CsA})$. The results are representative of three different experiments.

of its receptor (47). Inhibition of CD40L expression by CsA was not due to inhibition of IL-2 expression because addition of IL-2 $(100 \mathrm{U} / \mathrm{ml})$ did not reverse CsA-mediated inhibition of CD40L mRNA or surface expression (data not shown).

The role of calcineurin in CD40L expression was further investigated using analogues of CsA with different affinities for cyclophilin and calcineurin. $\mathrm{MeBm}_{2} \mathrm{t}^{1}-\mathrm{CsA}$, which has a much lower affinity for cyclophilin than CsA ( $K_{\mathrm{i}} 500 \mathrm{nM}$ vs 6.0$)$ but whose cyclophilin complex has a higher affinity for calcineurin $\left(K_{\mathrm{i}} 13 \mathrm{nM}\right.$ vs 40 ) (22), inhibited PMA- and ionomycin-induced CD40L surface expression (Fig. 4). $\mathrm{MeBm}_{2} \mathrm{t}^{\mathrm{t}}-\mathrm{CsA}$ at $150 \mathrm{ng} / \mathrm{ml}$ almost completely inhibited PMA- and ionomycininduced $\mathrm{CD} 40 \mathrm{~L}$ expression and therefore was only slightly less active than CsA despite an 80-90-fold weaker affinity for cyclophilin. MeAla ${ }^{6}$-CsA, which has a slightly lower affinity for cyclophilin than CsA ( $K_{\mathrm{i}} 9.0 \mathrm{nM}$ vs 6.0$)$ but whose cyclophilin complex has a much lower affinity for calcineurin $\left(K_{\mathrm{i}}>1\right.$ $\times 10^{3} \mathrm{nM}$ vs 40) (22), did not inhibit PMA- and ionomycininduced $\mathrm{CD} 40 \mathrm{~L}$ surface expression even at concentrations as high as $1 \mu \mathrm{g} / \mathrm{ml}$ (Fig. 4 ). These results indicate that calcineurin
CsA (ng/ml):
PMA+lo:

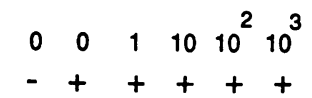
CD40L

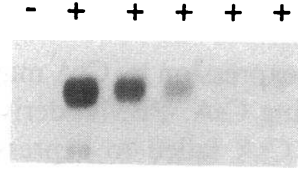
IL-2

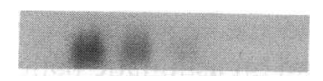
IL-2R

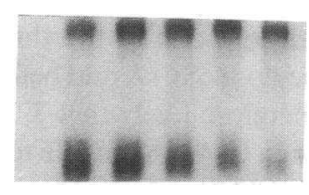
$28 S$
RNA

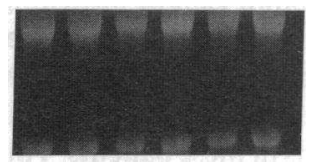
Figure 3. Inhibition of CD40L mRNA expres- sion by CsA. T cells were preincubated with the indicated concentra- tions of CsA for $1 \mathrm{~h}$ be- fore stimulation with PMA and ionomycin. CsA inhibited CD40L and IL-2 mRNA ex- pression in a concentra- tion-dependent manner. IL-2R $\alpha$ mRNA expres- sion was minimally af- fected by CsA. Ethi- dium bromide staining of $18 \mathrm{~S}$ and 28S RNA is shown to illustrate the relative concentrations of RNA. The results are representative of three $18 S$ different experiments.

has a direct role in the signaling pathway regulating CD40L expression.

The functional importance of CsA-induced inhibition of CD40L expression was investigated by assessing the effect of CsA on immunoglobulin isotype switching to IgE. IL-4-induced IgE isotype switching in PBMC is T cell dependent (1) and is inhibited by SCD40 (12), indicating that CD40L expression by $T$ cells plays a critical role in T cell-dependent IL-4driven IgE isotype switching. Table I shows that CsA inhibited $T$ cell-dependent IL-4-induced IgE synthesis in PBMC derived from three different individuals. The effect of CsA was exerted at the $T$ cell level because CsA did not inhibit $T$ cell-independent IgE synthesis induced by CD40 mAb and IL-4. Therefore inhibition of CD40L expression by CsA is associated with inhibition of CD40L-mediated T cell-dependent $B$ cell function.

Finally, we investigated CD40L expression in PBMC derived from CsA-treated transplant recipients. One patient was studied before and $3 \mathrm{~h}$ after the administration of a single dose of $4 \mathrm{mg} / \mathrm{kg}$ CsA within the period when blood CsA levels peak, 2-4 h after oral administration (48). Fig. $5 A$ shows that PBMC derived from the patient before the administration of CsA expressed CD40L after stimulation with PMA and ionomycin. Administration of a single dose of CsA inhibited, within $3 \mathrm{~h}$, CD40L expression in PBMC. This effect was selective to CD40L because administration of CsA did not inhibit PMAand ionomycin-induced IL-2R $\alpha$ expression. Two other kidney transplant patients who were receiving $\mathrm{CsA}$ and low dose alternate day prednisone were also studied. In contrast to PBMC derived from healthy adult subjects or from an asthmatic patient receiving equivalent doses of alternate day steroids, PBMC derived from the transplant patients receiving CsA and alternate day steroids failed to express CD40L on their surface upon stimulation with PMA and ionomycin (Fig. 5 B). PBMC from patients and controls expressed IL-2R $\alpha$ normally. Therefore, administration of CsA in vivo inhibits PMA- and ionomycin-induced CD40L expression in PBMC.

\section{Discussion}

Our results suggest that CD40L gene expression in T lymphocytes is under strict regulatory control. Both activation of PKC 


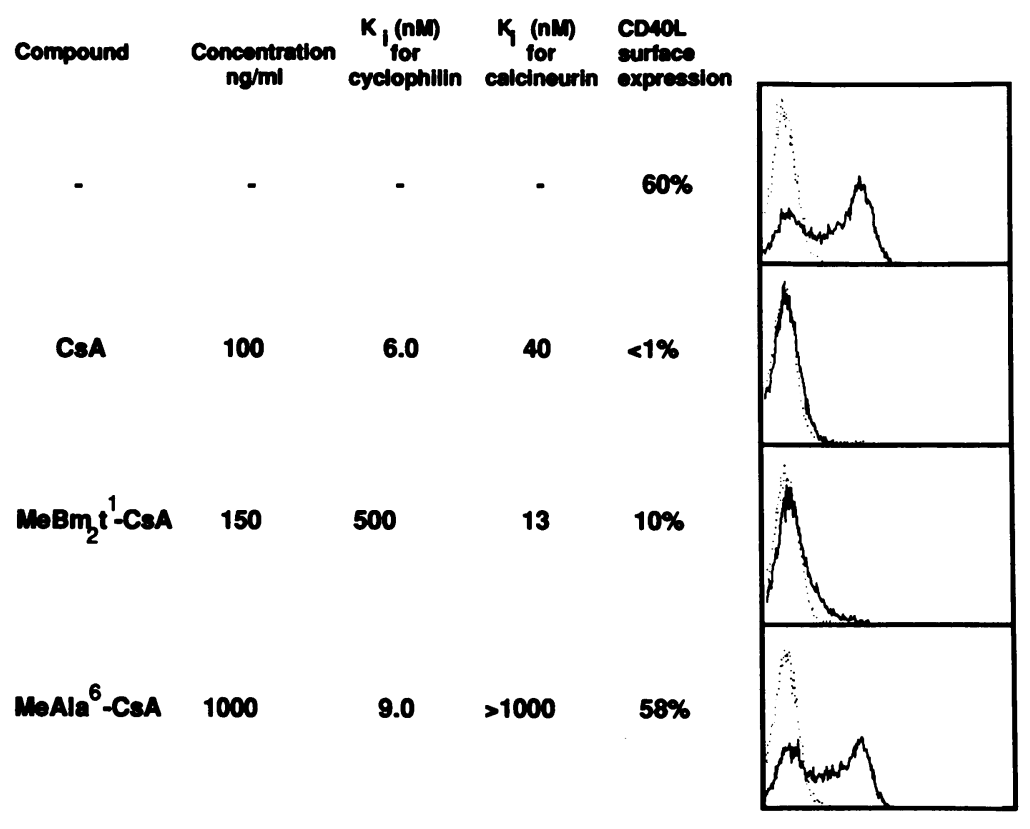

Figure 4. Effect of CsA analogues on the expression of CD40L. T cells were preincubated with medium alone or with increasing concentrations of CsA or its analogues $\mathrm{MeBm}_{2} \mathrm{t}^{1}$-CsA and MeAla ${ }^{6}$-CsA for $1 \mathrm{~h}$ before stimulation with PMA and ionomycin. The relative affinities of CsA and its analogues to cyclophilin and to calcineurin

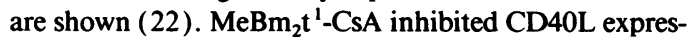
sion by $60 \%$ at $100 \mathrm{ng} / \mathrm{ml}$ (data not shown) and by $85 \%$ at $150 \mathrm{ng} / \mathrm{ml}$. However, MeAla ${ }^{6}$-CsA did not inhibit $\mathrm{CD} 40 \mathrm{~L}$ expression at concentrations ranging from 100 $\mathrm{ng} / \mathrm{ml}$ to $1 \mu \mathrm{g} / \mathrm{ml}$ (data for $1 \mu \mathrm{g} / \mathrm{ml}$ shown). Binding of sCD44 and sCD40 are shown in dotted and continuous lines, respectively. The results are representative of three different experiments.

and a rise in $\left[\mathrm{Ca}^{2+}\right]_{i}$ are required for CD40L gene expression. CD40L mRNA is detectable as early as $1 \mathrm{~h}$ after stimulation but disappears by $16 \mathrm{~h}$. Similarly, CD40L surface expression is detectable as early as $\mathbf{3} \mathrm{h}$ after stimulation and is barely detectable by $16 \mathrm{~h}$.

CsA inhibited CD40L mRNA and surface expression without significantly affecting IL-2R $\alpha$ mRNA or surface expression. CsA appears to exert its inhibitory effect through inhibition of the $\mathrm{Ca}^{2+}$ /calmodulin-dependent protein phosphatase calcineurin. The ability of CsA analogues to inhibit CD40L expression correlated with the ability of each compound to inhibit calcineurin activity. These results indicate that calcineurin plays a key role in the activation of CD40L gene expression.

Experiments involving overexpression of calcineurin in Jurkat $\mathrm{T}$ cells suggest that NF-AT is a target of calcineurin (35). More recently, NF-AT has been shown to be a substrate for calcineurin in vitro (38). It is therefore likely that NF-AT may play an important role in the regulation of transcription of the CD40L gene. A role for NF-AT may also explain the requirement for activation of PKC. PKC activates several nuclear transcription factors including members of the fos and jun family of proteins which participate in a functional NF-AT

Table I. Effect of CsA on CD4OL-dependent IgE Isotype Switching

\begin{tabular}{|c|c|c|c|c|c|}
\hline \multirow[b]{2}{*}{ Subject } & \multirow[b]{2}{*}{ Medium } & \multicolumn{2}{|c|}{ IL-4 } & \multicolumn{2}{|c|}{ CD40 mAb plus IL-4 } \\
\hline & & - & $+\operatorname{Cs} A$ & - & $+\mathrm{CsA}$ \\
\hline 1 & 290 & 13,900 & 2,700 & 24,300 & 28,200 \\
\hline 2 & 100 & 27,700 & 20 & 22,900 & 24,000 \\
\hline 3 & 10 & 4,300 & 50 & 37,800 & 39,300 \\
\hline
\end{tabular}

PBMC derived from three healthy volunteers were stimulated for IgE synthesis (picograms per milliliter) as described in Methods. CsA was added where indicated at a concentration of $100 \mathrm{ng} / \mathrm{ml}$. CsA inhibited IL-4-induced CD40L-dependent IgE synthesis but did not inhibit $T$ cell-independent IgE synthesis induced by CD40 mAb plus IL-4. complex (49-51). However, it is also possible that other transcription factors activated by calcineurin and/or by PKC, such as NF-IL2A ( 35 ) may play an important role in the expression of the CD40L gene. The exact determination of the regulatory elements which control transcription of the CD40L gene awaits detailed characterization of the human CD40L 5 ' regulatory region. Preliminary data generated in our laboratory indicate the presence of NF-AT-like sequences in the 5 ' region of the mouse CD40L gene and that nuclear extracts obtained from activated $\mathrm{T}$ cells bind to these sequences in electromobility shift assays. This supports the notion that CsA may inhibit CD40L expression by inhibiting calcineurin-dependent NFAT activation.

Inhibition of CD40L expression by CsA prevented $\mathrm{T}$ cells from delivering CD40L-dependent signals to $B$ cells. The induction of IgE synthesis in PBMC is T cell dependent ( 1 ) and is mediated by CD40L (12). In contrast, CD40 mAb and IL-4 induce $\mathrm{T}$ cell-independent IgE synthesis. CsA inhibited T celldependent IL-4-driven IgE synthesis in PBMC but did not inhibit IgE synthesis induced by CD40 mAb and IL-4. These results indicate that $\mathrm{CsA}$ inhibited CD40L-dependent IgE isotype switching.

Inhibition of CD40L expression by CsA may have implications for patients receiving CsA. PBMC derived from transplant patients receiving CsA failed to express CD40L upon stimulation with PMA and ionomycin. Inhibition of CD40L expression was not due to the concurrent use of steroids because PBMC derived from an asthmatic patient, receiving an equivalent dose of alternate day steroids, expressed CD40L upon stimulation. In addition, one of the three patients was studied after receiving one dose of CsA and before the administration of steroids. It is therefore likely that $\mathrm{T}$ lymphocytes, in transplant patients receiving CsA, are unable to interact with $\mathrm{B}$ cells through the CD40L/CD40 axis in vivo. Since CD40L is essential for immunoglobulin isotype switching (13), patients receiving CsA may not be able to undergo immunoglobulin isotype switching in response to newly encountered antigens. Administration of intravenous immunoglobulin may decrease the frequency of infections in these patients. This may be partic- 
A

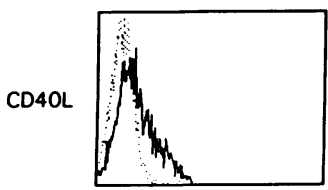

$\operatorname{CD} 25$

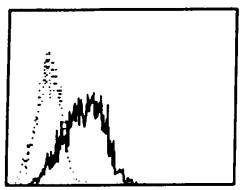

Post CsA
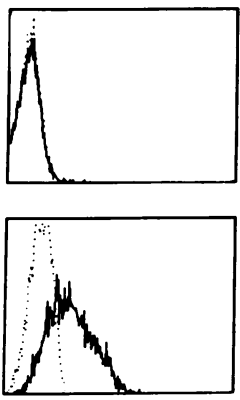

B
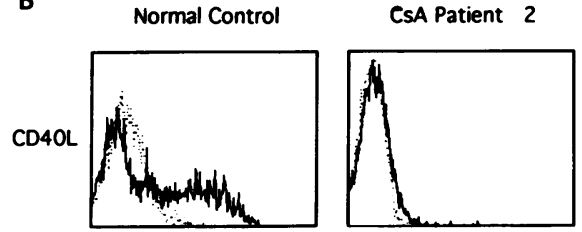

CsA Patient 3

Asthma Control
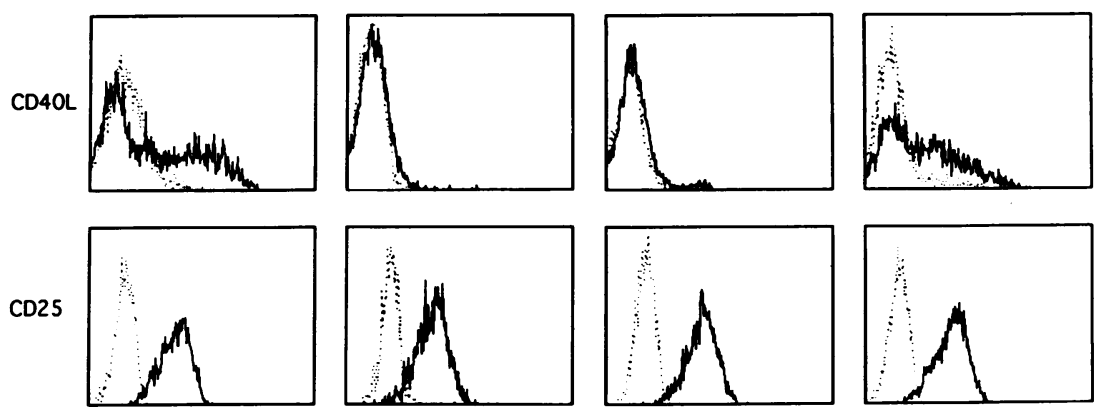

Figure 5. Administration of CsA in vivo inhibits CD40L in PBMC. PBMC were stained for CD40L $6 \mathrm{~h}$ after stimulation with PMA and ionomycin and for IL-2R $\alpha 24 \mathrm{~h}$ after stimulation. CD40L and CD25 are shown by a continuous line, and relevant isotype controls are shown by a dotted line. ( $A$ ) PBMC derived from a transplant patient expressed CD40L before the administration of CsA but not $3 \mathrm{~h}$ after the administration of a single dose of CsA. IL-2R $\alpha$ expression was not inhibited by CsA. (B) PBMC derived from two transplant patients receiving CsA and alternate day steroids failed to express CD40L but expressed IL-2R $\alpha$ normally. PBMC derived from control subject and from an asthmatic patient receiving alternate day steroids expressed CD40L and IL-2R $\alpha$ after stimulation.

ularly significant in pediatric patients who may not have had the opportunity to develop a wide range of antibodies before receiving CsA. Further studies are needed to demonstrate an effect of CsA on in vivo antibody responses.

\section{Acknowledgments}

We thank Mary Drew for her assistance.

This work was supported by U.S. Public Health Service grants RR02172, AI31136, and AI31541 to R. S. Geha and CA55735 to I. Stamenkovic; by a grant from the March of Dimes 6-0760 (R. S. Geha); and by grants from Caremark, Critical Care of America and Home Nutritional Services. R. Fuleihan is supported by grants from the Immune Deficiency Foundation (Cutter Award) and the Lucille P. Markey trust. I. Stamenkovic is a scholar of the Leukemia Society of America. Work done by D. G. Alberg and P. J. Belshaw in the laboratories of S. L. Schreiber (Department of Chemistry, Harvard University) was supported by grants from the National Institute of General Medical Sciences (GM-38627 and GM-40660 to S. L. Schreiber), a National Sciences and Engineering Research Council postgraduate fellowship (to P. J. Belshaw), and a National Institutes of Health postdoctoral fellowship (to D. G. Alberg).

\section{References}

1. Vercelli, D., H. H. Jabara, K.-I. Arai, and R. S. Geha. 1989. Induction of human IgE synthesis requires interleukin 4 and $T / B$ cell interactions involving the $\mathrm{T}$ cell receptor/CD3 complex and MHC class II antigens. J. Exp. Med. 169:1295-1307.

2. Armitage, R. J., W. C. Fanslow, L. Strockbine, T. A. Sato, K. N. Clifford, B. M. Macduff, D. M. Anderson, S. D. Gimpel, T. Davis-Smith, C. R. Maliszewski, et al. 1992. Molecular and biologic characterization of a murine ligand for CD40. Nature (Lond.). 357:80-82.

3. Noelle, R. J., M. Roy, D. M. Shepherd, I. Stamenkovic, J. A. Ledbetter, and A. Aruffo. 1992. A 39-kDa protein on activated helper T cells binds CD40 and transduces the signal for cognate activation of B cells. Proc. Natl. Acad. Sci. USA. 89:6550-6554.

4. Hollenbaugh, D., L. S. Grosmaire, C. D. Kullas, N. J. Chalupny, S. Braesch-Anderson, R. J. Noelle, I. Stamenkovic, J. A. Ledbetter, and A. Aruffo. 1992. The human T cell antigen gp39, a member of the TNF gene family, is a ligand for the CD40 receptor: expression of a soluble form of $\mathrm{gp} 39$ with B cell co-stimulatory activity. EMBO (Eur. Mol. Biol. Organ.) J. 11:4313-4321.

5. Graf, D., U. Korthauer, H. W. Mages, G. Senger, and R. A. Kroczek. 1992. Cloning of TRAP, a ligand for CD40 on human T cells. Eur. J. Immunol. 22:3191-3194.

6. Stamenkovic, I., E. A. Clark, and B. Seed. 1989. A B-lymphocyte activation molecule related to the nerve growth factor receptor and induced by cytokines in carcinomas. EMBO (Eur. Mol. Biol. Organ.) J. 8:1403-1410.

7. Jabara, H. H., S. M. Fu, R. S. Geha, and D. Vercelli. 1990. CD40 and IgE:
Synergism between anti-CD40 monoclonal antibody and interleukin 4 in the induction of IgE synthesis by highly purified human B cells. J. Exp. Med. 172:1861-1864.

8. Barrett, T. B., G. Shu, and E. A. Clark. 1991. CD40 signalling activates CD1 1a/CD18 (LFA-1)-mediated adhesion in B cells. J. Immunol. 146:17221729.

9. Lederman, S., M. J. Yellin, A. Krichevsky, J. Belko, J. J. Lee, and L. Chess. 1992. Identification of a novel surface protein on activated $\mathrm{CD}^{+}{ }^{+} \mathrm{T}$ cells that induces contact-dependent B cell differentiation (help). J. Exp. Med. 175:10911101.

10. Spriggs, M. K., R. J. Armitage, L. Strockbine, K. N. Clifford, B. M. Macduff, T. A. Sato, C. R. Maliszewski, and W. C. Fanslow. 1992. Recombinant human CD40 ligand stimulates $B$ cell proliferation and immunoglobulin E secretion. J. Exp. Med. 176:1543-1550.

11. Lane, P., T. Brocker, S. Hubele, E. Padovan, A. Lanzavecchia, and F. McConnell. 1993. Soluble CD40 ligand can replace the normal T cell-derived CD40 ligand signal to B cells in T cell-dependent activation. J. Exp. Med. 177:1209-1213.

12. Fanslow, W., D. Anderson, K. H. Grabstein, E. A. Clark, D. Cosman, and R. Armitage. 1992. Soluble forms of CD40 inhibit biologic responses of human B cells. J. Immunol. 149:655-660.

13. Fuleihan, R., N. Ramesh, R. Loh, H. Jabara, F. S. Rosen, T. Chatila, S. M. Fu, I. Stamenkovic, and R. S. Geha. 1993. Defective expression of the CD40 ligand in $\mathrm{X}$ chromosome-linked immunoglobulin deficiency with normal or elevated IgM. Proc. Natl. Acad. Sci. USA. 90:2170-2173.

14. Ramesh, N., R. Fuleihan, V. Ramesh, S. Sharma, F. S. Rosen, and R. S. Geha. 1993. Mutations in the T cell antigen CD40 ligand in X-linked immunoglobulin deficiency with normal or elevated IgM (HIGMX-1). Int. Immunol. 5:769-773.

15. Aruffo, A. M. Farrington, D. Hollenbaugh, $X$. Li, A. Milatovich, $\mathbf{S}$ Nonoyama, J. Bajorath, L. S. Grosmaire, R. Stenkamp, M. Neubauer, et al. 1993. The CD40 ligand, gp39, is defective in activated T cells from patients with Xlinked hyper IgM syndrome. Cell. 72:291-300.

16. Korthauer, U., D. Graf, H. W. Mages, F. Briere, M. Padayachee, S. Malcolm, A. G. Ugazio, L. D. Notarangelo, R. J. Levinsky, and R. A. Kroczek. 1993. Defective expression of T-cell CD40 ligand causes X-linked immunodeficiency with hyper-IgM. Nature (Lond.). 361:539-541.

17. DiSanto, J. P., J. Y. Bonnefoy, J. F. Gauchat, A. Fischer, and G. de Saint Basile. 1993. CD40 ligand mutations in X-linked immunodeficiency with hyperIgM. Nature (Lond.). 361:541-543.

18. Allen, R. C., R. J. Armitage, M. E. Conley, H. Rosenblatt, N. A. Jenkins, N. G. Copeland, M. A. Bedell, S. Edelhoff, C. M. Disteche, D. K. Simoneaux et al. 1993. CD40 ligand gene defects responsible for X-linked hyper-IgM syndrome. Science (Wash. DC). 259:990-993.

19. Geha, R. S., N. Hyslop, S. Alami, F. Farah, E. E. Schneeberger, and F. S Rosen. 1979. Hyper immunoglobulin M immunodeficiency (dysgammaglobulinemia ). Presence of immunoglobulin $\mathbf{M}$-secreting plasmacytoid cells in peripheral blood and failure of immunoglobulin $\mathrm{M}$-immunoglobulin $\mathrm{G}$ switch in B-cell differentiation. J. Clin. Invest. 64:385-391.

20. Levitt, D., P. Haber, K. Rich, and M. D. Cooper. 1983. Hyper IgM immunodeficiency. A primary dysfunction of B lymphocyte isotype switching. J. Clin. Invest. 72:1650-1657.

21. Notarangelo, L. D., M. Duse, and A. G. Ugazio. 1992. Immunodeficiency with hyper-IgM (HIM). Immunol. Rev. 3:101-122. 
22. Liu, J., M. W. Albers, T. J. Wandless, S. Luan, D. G. Alberg, P. J. Belshaw, P. Cohen, C. MacKintosh, C. B. Klee, and S. L. Schreiber. 1992. Inhibition of T cell signaling by immunophilin-ligand complexes correlates with loss of calcineurin phosphatase activity. Biochemistry. 31:3896-3901.

23. Stamenkovic, I., M. Amiot, J. M. Pesando, and B. Seed. 1989. A lymphocyte molecule implicated in lymph node homing is a member of the cartilage link protein family. Cell. 56:1057-1062.

24. Aruffo, A., I. Stamenkovic, M. Melnick, C. B. Underhill, and B. Seed. 1990. CD44 is the principal cell surface receptor for hyaluronate. Cell. 61:13031313.

25. Gruber, M. F., J. M. Bjorndahl, S. Nakamura, and S. M. Fu. 1989. AntiCD45 inhibition of human B cell proliferation depends on the nature of activation signals and the state of B cell activation. J. Immunol. 142:4144-4152.

26. Park, D. J., H. W. Rho, and S. G. Rhee. 1991. CD3 stimulation causes phosphorylation of phospholipase $\mathrm{C} \gamma \mathrm{l}$ on serine and tyrosine residues in a human T cell line. Proc. Natl. Acad. Sci. USA. 88:5453-5456.

27. Secrist, J. P., L. Karnitz, and R. T. Abraham. 1991. T-cell antigen receptor ligation induces tyrosine phosphorylation of phospholipase C- $\gamma 1$. J. Biol. Chem 266:12135-12139.

28. Weiss, A., G. Koretzky, R. C. Schatzman, and T. Kadlecek. 1991. Functional activation of the $T$ cell antigen receptor induces tyrosine phosphorylation of phospholipase C $\gamma 1$. Proc. Natl. Acad. Sci. USA. 88:5484-5488.

29. Dasgupta, J. D., C. Granja, B. Druker, L. Lin, E. J. Yunis, and V. Relias. 1992. Phospholipase $\mathrm{C} \gamma 1$ association with CD3 structure in T cells. J. Exp. Med. 175:285-288.

30. Nishibe, S., M. I. Wahl, S. M. Hernandez-Stomomayor, N. K. Tonk, S. G. Rhee, and G. Carpenter. 1990. Increase in the catalytic activity of phospholipase C- $\gamma 1$ by tyrosine phosphorylation. Science (Wash. DC). 250:1253-1256.

31. Nishizuka, Y. 1984. The role of protein kinase $C$ in cell surface signal transduction and tumour promotion. Nature (Lond.). 308:693-698.

32. Berridge, M. J., and R. F. Irvine. 1984. Inositol trisphosphate, a nove second messenger in cellular signal transduction. Nature (Lond.). 312:315-321.

33. Imboden, J. B., and J. D. Stobo. 1985. Transmembrane signaling by the T cell antigen receptor. Perturbation of the T3-antigen receptor complex generates inositol phosphates and releases calcium ions from intracellular stores. J. Exp. Med. 161:446-456.

34. Chatila, T., L. Silverman, R. Miller, and R. Geha. 1989. Mechanisms of T cell activation by the calcium ionophore ionomycin. J. Immunol. 143:12831289.

35. Clipstone, N. A., and G. R. Crabtree. 1992. Identification of calcineurin as a key signalling enzyme in T-lymphocyte activation. Nature (Lond.). 357:695697.

36. O'Keefe, S. J., and J. T. Tamura. 1992. FK-506- and CsA-sensitive activation of the interleukin-2 promoter by calcineurin. Nature (Lond.). 357:692-694.

37. Schreiber, S. L., and G. R. Crabtree. 1992. The mechanism of action of cyclosporin A and FK506. Immunol. Today. 13:136-142.
38. Jain, J., P. G. McCaffrey, Z. Miner, T. K. Kerppola, J. N. Lambert, G. L. Verdine, T. Curran, and A. Rao. 1993. The T-cell transcription factor NFATp is substrate for calcineurin and interacts with Fos and Jun. Nature (Lond.) 365:352-355.

39. Flanagan, W. F., B. Corthesy, R. J. Bram, and G. R. Crabtree. 1991. Nuclear association of a T-cell transcription factor blocked by FK- 506 and cyclosporin A. Nature (Lond.). 352:803-807.

40. Handschumacher, R. E., M. W. Harding, J. Rice, R. J. Drugge, and D. W. Speicher. 1984. Cyclophilin: a specific cytosolic binding protein for cyclosporin A. Science (Wash. DC) . 226:544-546.

41. Liu, J., J. D. Farmer, W. S. Lane, J. Friedman, I. Weissman, and S. L. Schrieber. 1991. Calcineurin is a common target of cyclophilin-cyclosporin A and FKBP-FK506 complexes. Cell. 66:807-815.

42. Fruman, D. A., C. B. Klee, B. E. Bierer, and S. J. Burakoff. 1992. Calcineurin phophatase activity in T lymphocytes is inhibited by FK 506 and cyclosporin A. Proc. Natl. Acad. Sci. USA. 89:3686-3690.

43. Kronke, M., W. J. Leonard, J. M. Depper, S. K. Arya, F. Wong-Staal, R. C. Gallo, T. A. Waldmann, and W. C. Greene. 1984. Cyclosporin A inhibits T cell growth factor gene expression at the level of mRNA transcription. Proc. Natl. Acad. Sci. USA. 81:5214-5218.

44. Leonard, W. J., J. M. Depper, G. R. Crabtree, S. Rudikoff, J. Pumphrey, R. J. Robb, M. Kronke, P. B. Svetlik, N. J. Peffer, T. A. Waldmann, and W. C. Greene. 1984. Molecular cloning and expression of cDNAs for the human interleukin-2 receptor. Nature (Lond.). 311:626-631.

45. Nikaido, T., A. Shimizu, N. Ishida, H. Sabe, K. Teshigawara, M. Maeda, T. Uchiyama, J. Yodoi, and T. Honjo. 1984. Molecular cloning of cDNA encoding human interleukin-2 receptor. Nature (Lond.). 311:631-635.

46. Reed, J. C., A. H. Abidi, J. D. Alpers, R. G. Hoover, R. J. Robb, and P. C. Nowell. 1986. Effect of cyclosporin A and dexamethasone on interleukin 2 receptor gene expression. J. Immunol. 137:150-154.

47. Depper, J. M., W. J. Leonard, C. Drogula, M. Kronke, T. A. Waldmann, and W. C. Greene. 1985. Interleukin 2 (IL-2) augments transcription of the IL-2 receptor gene. Proc. Natl. Acad. Sci. USA. 82:4230-4234.

48. Handschumaker, R. E. 1990. Immunosuppressive agents. In The Pharmacological Basis of Therapeutics. A. G. Gilman, T. W. Rall, A. S. Nies, P. Taylor, editors. McGraw-Hill Inc., New York. 1264-1274.

49. Castigli, E., T. A. Chatila, and R. S. Geha. 1993. A protein of the AP-1 family is a component of nuclear factor of activated T-cells (NFAT). J. Immunol. 150:3284-3290.

50. Boise, L. H., B. Petryniak, X. Mao, C. H. June, C.-Y. Wang, T. Lindsten, R. Bravo, K. Kovary, J. M. Leiden, and C. B. Thompson. 1993. The NFAT-1 DNA binding complex in activated T cells contains Fra-1 and JunB. Mol. Cell. Biol. 13:1911-1919.

51. Jain, J., P. G. McCaffrey, V. E. Valge-Archer, and A. Rao. 1992. Nuclear factor of activated T cells contains Fos and Jun. Nature (Lond.). 356:801-804. 